\title{
The Angel of Death in Clarksburg
}

It is easy to go down into Hell; night and day, the gates of dark Death stand wide; but to climb back again, to retrace one's steps to the upper air-there's the rub, the task.

Virgil, The Aeneid

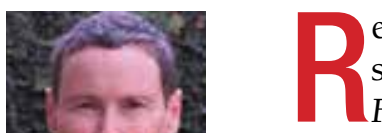

$R$ eaders of this column may recall that since I have been the Editor-in-Chief of Federal Practitioner, my December editorial focuses on the best and worst of the year in federal medicine. In 2021, these evaluative terms fail to capture the sadness and global devastation that mark this grim epoch of the continuing pandemic, increasing climate disasters, rising political tensions, and racial violence. Thus, this year my editorial is framed in terms of the philosophical or theological categories of good and evil as the only concepts that can even begin to express the horrendous events that occurred in West Virginia.

On June 28, 2018, then US Department of Veterans Affairs (VA) Veterans Health Administration (VHA) Executive-in-Charge, Carolyn Clancy, MD, contacted Inspector General Michael Missal to alert him that "there may be an 'Angel of Death' in Clarksburg [West Virginia]." Two years later Reta Mays, a 46-yearold VA nursing assistant, entered a guilty plea in federal court to the deaths of 7 vulnerable veterans. The legal charges were second-degree murder and 1 count of assault with intent to commit murder by injecting insulin. The victims were all patients on Ward 3 at the Louis A. Johnson VA, Medical Center in Clarksburg, where Mays worked the night shift from 2015 to 2018. ${ }^{2}$ Mays was sentenced in May of this year to 7 consecutive life terms for each of the veterans whose lives she cruelly ended and an additional 240 months for the eighth patient who survived her murder attempt. ${ }^{3}$

The term angel of death has religious roots in Judaism, although not strictly in the Hebrew scriptures. Neither the Jewish nor Christian Bible identifies a specific figure who is the angel of death. The idea first appears in Rabbinic literature and Jewish tradition. ${ }^{4}$ The angel God sends as a messenger of death is known as malakh ha-mavet in Hebrew. The revered Jewish physician and philosopher Moses Maimonides taught in his Guide for the Perplexed the angel of death is synonymous with the devil, and the evil inclination that dwells in the mind of all human beings. ${ }^{5}$

In modern times, the concept of an angel of death has come to designate a serial killer who is a health care professional (HCP). A group of forensic scientists, HCPs, and attorneys, including former VA Under Secretary for Health Dr. Kenneth Kizer, published a study of HCPs who had been prosecuted or convicted of serial murder. Nurses constituted the largest group of offenders (60\%) with nursing aides like Mays responsible for $18 \%$ of murders, and physicians $12 \%$. The review found that though health care serial killers are rare, they operate in nations across the Western world, in many different states in this country, and in almost all health care settings, including previous VA angels of death. ${ }^{6}$

Nursing aides who are not supposed to have access to medications-a major problem in Mays' case-nor permitted to administer them more often resort to noncontrolled substances to kill their victims. ${ }^{1}$ Mays chose insulin as her murder weapon as did $13 \%$ of serial killers. Just as insulin may be difficult to detect in toxicology, so Mays and others like her committed their crimes on the night shift when they were less likely to be discovered. ${ }^{6}$

Many of us feel compelled to seek a rational motivation for why healers would mutate into killers: If we can find a reason for this heinous behavior it somehow helps us feel the world is more intelligible and controllable. Unfortunately, despite intensive forensic investigations of multiple angels of death, there is little definitive understanding of the motives of these murders. ${ }^{6}$ Mays disclosed more than most. As part of a plea bargain, she provided investigators with 2 rationales for her killing: She wanted to ease the patients' suffering. Such claims of being an angel of mercy are common among HCP serial murders, which the patterns of the killings generally disprove. The patients Mays lethally injected, while mostly old and ill, were 
all expected to recover and leave the hospital. The Inspector General report uncovered a cautionary detail that has at least indirect bearing on the nursing assistant's contention that she "wanted to let the patient's die gently": Contrary to VHA requirements, the facility had no functioning palliative care team. This finding in no way excuses or even explains Mays' actions; it does, however, reinforce the essential value of palliative care expertise in an aging veteran population with many life-limiting conditions. $^{7}$

Mays' second motivation seems more plausible, based on her life narrative and the literature on HCP serial killers. Mays disclosed to investigators that she "had a lot of stress and chaos in [her] personal and professional life and these actions gave [her] a sense of control." ${ }^{1}$ Her prior use of excessive force when employed at a prison as well as forensic science indicating that feelings of wielding power over life and death often drive health care murders, suggest this may have been a factor in Mays' horrific conduct. ${ }^{8}$

It seems blasphemous to associate the word good in the same pages with this terrible evil. Nothing can compensate or justify the betrayal of the sacred oath of an HCP and the public trust of a VHA employee. Yet that very impossibility carries with it an obligation to ask, as did the author of an article about a recent Canadian nurse serial killer, "What can we learn from the [Mays] story?" 9

Mays could never have taken the lives of 8 patients without clinical and administrative lapses and shortcuts at all levels of the health care system. Indeed, the 100-plus page Inspector General report makes 15 recommendations for the VHA, the Veterans Integrated Service Network, and the facility, encompassing areas of personnel hiring and performance evaluation, medication management and security, reporting and responding to unexplained events, quality and safety programs oversight, leaders' responses, corrective actions, and even computer systems data analysis.

I want to suggest 2 ethical additions to this list addressed to all of us as VHA staff and especially to those of us who are HCPs. From the perspective of virtue ethics, Reta Mays is a trag- edy about complacency and compromise in everyday work that the pandemic has made even more frequent and challenging to avoid and resist. This is what the Roman Virgil means in the epigraph that the road down to hell is easy and the road back very difficult.

I propose the need for discernment in trying to listen to our moral intuitions that tell us something is amiss and diligence in adhering to best practices even when we are fearful, exhausted, demoralized, or apathetic. These 2 habits of commitment to veterans, one of compassion and the other of competence, can help us follow the good inclinations of our hearts and together with system changes can bar the doors of our hospitals to the visits of future angels of death. This dedication is the least we owe to the families of the patients at Clarksburg whose loved ones never came home and whose questions likely can never be fully answered.

\section{Disclaimer}

The opinions expressed herein are those of the author and do not necessarily reflect those of Federal Practitioner, Frontline Medical Communications Inc., the US Government, or any of its agencies.

\section{References}

1. US Department of Veterans Affairs, Office of Inspector General. Veterans Health Administration: care and oversight deficiencies related to multiple homicides at the Louis A. Johnson VA Medical Center in Clarksburg, West Virginia. Healthcare Inspection Report \#20-035993-140. Published May 112021. Accessed November 22, 2021. https://www.va.gov/oig/pubs NAOIG-20-03593-140.pdf

2. Kennedy M, Schwartz M. Former VA medical worker pleads guilty to murdering 7 patients in West Virginia. Published July 14, 2020. Accessed November 22, 2021. https:// www.npr.org/2020/07/14/890776010/former-va-medical -worker-charged-with-7-murders-in-west-virginia

3. US Department of Justice, US Attorney's Office Northern District of West Virginia. Former VA hospital nursing assistant sentenced to seven consecutive life sentences for murdering seven veterans and assault with intent to commit murder of an eighth [press release]. Published May 11, 2021. Accessed November 22, 2021. https://www.justice.gov/usao-ndwv /pr/former-va-hospital-nursing-assistant-sentenced-seven -consecutive-life-sentences.

4. Jacobs L. The Jewish Religion: A Companion. 1st ed. Oxford University Press; $1995: 116$.

5. Maimonides. Guide for the Perplexed. Frielander M, trans. Routledge and Kegan Paul Ltd; 1904:pt 3, chap 22.

6. Yorker BC, Kizer KW, Lampe P, Forrest AR, Lannan JM, Russell DA. Serial murder by healthcare professionals. J Forensic Sci. 2006;51(6):1362-1371. doi:10.1111/j.1556-4029.2006.00273.x

7. VHA Directive 1139. Palliative care consult teams (PCCT) and VISN leads. Published June 14, 2017.

8. Rourke S, Ward T. Healthcare serial killers: patterns and policies. Published August 14, 2017. Accessed November 22, 2021. https://www.medscape.com/viewarticle/884136

9. Frank C. Health care serial murder: what can we learn from the Wettlaufer story? Can Fam Physician. 2020;66(10) :719-722. 